Nomlomo, V. (2013). Preparing isiXhosa home language teachers for the 21st century

classroom: Student teachers' experiences, challenges and reflections. Southern African

Linguistics and Applied Language Studies, 31(2): 207-217

http://dx.doi.org/10.2989/16073614.2013.815887

UNIVERSITY of the WESTERN CAPE

\title{
Preparing isiXhosa home language teachers for the 21st century classroom: Student teachers' experiences, challenges and reflections
}

\author{
Vuyokazi Nomlomo
}

\begin{abstract}
The aim of the article is to identify the gaps between theory and practice in pre-service teacher training with special reference to the teaching of isiXhosa as a home language in the Further Education and Training (FET) phase (Grades 10-12) in some Western Cape high schools. The article is based on data that was collected from Postgraduate Certificate in Education (PGCE) students taking isiXhosa (home language) as one of their teaching method subjects as part of their pre-service training. The data were collected by means of an open-ended questionnaire, semi-structured interviews and an analysis of student teachers' reflective journals. The article provides an analysis of PGCE students' experiences and reflections on the teaching of isiXhosa as a home language in schools. It argues that if there is a gap between theory underpinning initial pre-service training and actual practice in schools, there will be no significant improvement in the teaching of isiXhosa as a home language. It concludes by proposing ways of improving both preservice and in-service teacher education practice to develop African languages as academic or intellectual languages at school level.
\end{abstract}

\section{Introduction}

South Africa is one of the countries in the world with rich cultural and linguistic diversity, with many languages spoken by a population of more than 50 million people, of which 11 are official languages, namely Afrikaans, English, isiNdebele, isiXhosa, isiZulu, Sepedi, Sesotho, Setswana, siSwati, Tshivenda and Xitsonga. Of the 11 official languages, 9 are African languages (Sepedi, Sesotho, Setswana, siSwati, Tshivenda, Xitsonga, isiNdebele, isiXhosa, isiZulu), which are spoken by the majority (72\%) of the South African population. IsiZulu and isiXhosa are the most widely spoken languages in the country: isiZulu is spoken by $23.82 \%$ of population, while isiXhosa speakers constitute $17.64 \%$ of the total South African population (Republic of South Africa Census, 2001). All the African languages are used as languages of learning and teaching in the Foundation Phase only (that is, from Grade 1-3), although they are taught as subjects from primary to tertiary education at 3 levels: as home languages, first additional or second additional languages.

All the official languages serve important socio-economic roles as means of communication and are needed for different careers, for instance in the media, marketing, advertising, translating, interpreting, etc. (Jordaane \& Pillay, 2009). The teaching and studying of African languages also follow the same learning outcomes and 
teaching principles or approaches as outlined in the outcomes-based National Curriculum Statement (DoE, 2005) which was adopted as a means of redress and equity in education after the apartheid education system. The new language curriculum promotes learnercentred, communicative, text-based and integrated approaches in and for all languages as subjects in order to develop learners' language skills, namely listening, speaking, reading, viewing, presenting, writing, critical thinking and appropriate language use (Murray, 2009; DoE, 2005).

Given the low socio-economic status of African languages in formal domains such as education and business, the new Language in Education Policy (DoE, 1997), which is informed by the democratic Constitution of the Republic of South Africa (RSA, 1996), aims at developing all the official African languages. However, there is a concern about the small numbers of students training as African language teachers across the country, a tendency that is most probably attributable to the perceived low socio-economic status of African languages and the low status accorded to the teaching profession (Whitelaw et al., 2008). Moreover, lack of teaching resources in and for African languages and lack of inservice training for practising African language teachers also raise concerns with regard to the quality of the teaching of these languages (Foley, 2001).

The teaching and learning of African languages as home languages in schools is an underresearched area. Recent research on African languages has focused mainly on their status in education (UNESCO, 2010; Gxilishe, 2009; Roy-Campbell, 2006; Foley, 2001) and the effects of learning through an additional language (for example, English) by African language speaking children have been widely researched in South Africa and in other African countries like Namibia and Tanzania (Nomlomo, 2007; Brock-Utne, 2005; Vuzo, 2005; Alidou, 2004; Webb, 2004; Desai, 2003; Heugh, 2003; Mwinsheikhe, 2003; Qorro, 2003; McKay \& De Klerk, 1996; Sentson, 1994). Research on the teaching of African languages has looked at how African languages are taught as additional languages, particularly at tertiary levels (Mbatha, 2010; Pluddeman et al., 2010). Since the new outcomes-based curriculum was introduced in the last decade, there has been a dearth of research on how African languages are taught as home languages, both at school and in higher education, and how Initial Teacher Education Programmes (ITEP) prepare student teachers to teach these languages at school level.

In light of the above, this article focuses on the preparation of student teachers to teach isiXhosa as a home language at the Further Education and Training (FET) band, that is, Grades 10-12. It is based on data collected from student teachers enrolled for a one year Postgraduate Certificate in Education (PGCE) qualification in one of the institutions of higher education in the Western Cape. The purpose of the article is threefold:

i. It explores student teachers' experiences and reflections on the teaching of isiXhosa at the FET level in order to gain an understanding of how they navigate their learning as student teachers in the FET isiXhosa classrooms. In other words, it explores how student teachers translate their theoretical knowledge into practice in the isiXhosa

\section{http://repository.uwc.ac.za}


home language classrooms. The aim is to challenge the perception, taken for granted, that student teachers' immersion in real classroom environments automatically translates into good teaching practices or performance (Rusznyak, 2009; Darling-Hammond \& Bransford, 2005).

ii. It examines the role of schools and isiXhosa teachers (or mentors) in nurturing student teachers in building their professional identity.

iii. It discusses possible strategies for improving the quality of teaching isiXhosa and other African languages at school level and the role of teacher education in producing teachers who can cope with the challenges experienced in the language classrooms of this century.

\section{Learning to teach: A socio-cultural perspective}

Learning to teach is a complex activity which requires acquisition, integration and application of different types of knowledge and skills (Kemmis, 2011; Fitzmaurice, 2010; DoE, 2005; Darling-Hammond \& Bransford, 2005). Student teachers are exposed to different kinds of knowledge in their training, namely disciplinary (content) knowledge and pedagogical knowledge, to which they are exposed through practical, fundamental and situational learning (DoE, 2005; Darling-Hammond \& Bransford, 2005). Disciplinary knowledge involves subject (discipline) matter knowledge, while pedagogical knowledge has to do with how (methods) to present the content of a particular subject or discipline to learners. The different forms of student knowledge influence the design of teacher education programmes, which have to incorporate that knowledge into their curricula. As a result, these programmes are usually designed according to content (what is taught), the learning process (practice) and the learning context (classroom environment and policies), which facilitate student teacher competences, namely practical, fundamental and reflexive competences. These competences enable the students to make informed decisions and to adapt their knowledge and practice in different situations (Grosser \& De Waal, 2008; DoE, 2005).

From a socio-cultural perspective (Vygotsky, 1978), learning to teach involves a practice which is socially constructed through interaction with various people, including learners, experienced teachers (or mentors) and peers (Kemmis, 2011; Fitzmaurice, 2010; DarlingHammond \& Bransford, 2005; Korthagen \& Kessels, 1999). This interaction requires supervision, coaching and constructive feedback so that students can make sense of the concepts learnt in the ITEP course- work and how to apply them in the classroom (Darling-Hammond \& Bransford, 2005). This indicates that learning to teach is a mediated process that involves cognitive and social processes of interaction between more capable and less capable individuals: 'experts' and 'novices' (Shrum \& Glisan, 2000: 7) who include teachers, peers and mentors. Thus the process of learning to teach is associated with scaffolding and Vygotsky's (1978) Zone of Proximal Development (ZPD) which entail the provision of assistance to the learner until they reach a stage when they can do the tasks without the expert's support (Ohta, 2000).

\section{http://repository.uwc.ac.za}


The learning process is influenced by teacher and learner beliefs, attitudes and prior experiences. In ITEP, teacher educators and practising teachers (mentors) who provide guidance and support to prospective teachers have their own beliefs and attitudes about teaching (Ashby et al., 2008). At the same time, the student teachers come with their own beliefs, diverse needs and expectations of learning to teach. If the student's preconceived beliefs conflict with the ITEP values, they may act as a barrier to the acquisition of the knowledge necessary for their professional development as prospective teachers. Consequently, student teachers may revert to the same old habits they experienced at school as learners, regardless of their exposure to new knowledge in the ITEP. This means that a clash between student teacher beliefs and ITEP courses/content usually creates a gap between theory (what they learn in ITEP courses) and practice (how they apply knowledge in the classroom) in the process of learning to teach (Korthagen \& Kessels, 1999). Other factors that influence student teacher practices negatively include overcrowded classrooms, limited time of guidance, and lack of support and supervision by mentors and teacher educators. Learning to teach is a complex process which cannot be measured in terms of teaching practice only.

The training of isiXhosa home language teachers should be understood in relation to the factors mentioned above, including the integration of theoretical and practical knowledge, the nature of the teaching practice context or environment, and practising teachers' and student teachers' prior experiences. In this article, the focus is on how student teachers experience and understand their world of practice as they learn to teach isiXhosa in the FET phase.

\section{Sample}

The study followed purposive and convenience sampling approaches in which nine PGCE students participated. The study was carried out over two years with different students four students in 2010 and five students in 2011 - for a deeper understanding of how student teachers were inducted into the teaching of isiXhosa home language in the FET phase and how their experiences influenced their own teaching practices in isiXhosa.

In the first cohort (2010) there was 1 male student and 3 female students, while the second cohort (2011) comprised 2 male students and 3 female students. All the students involved in the study were home language speakers of isiXhosa and had graduated with isiXhosa (Xhosa III) as one of their majors in their undergraduate studies. All of them were taking isiXhosa as a teaching method in their PGCE studies, and were willing to participate in the study. Two of the students in the 2011 cohort had graduated with an honours degree in isiXhosa. The students' age range was between 23 and 45 years; 6 of them matriculated in the mid- and late-1990s, while 2 of the 2011 cohort matriculated in 2007. The student teachers brought diverse work experiences, such as pre-school and adult education teachers with no professional training, cashiers in retail stores, security guards and business or self-employed people.

\section{http://repository.uwc.ac.za}


As part of their training, the students spent approximately 12 weeks in schools over 3 teaching practice sessions to gain experience from at least 3 different schools. In the first and second terms, they spent 1 week in each school to observe teachers. They spent the third term in 1 school for an extended period of about 10 weeks where they had to observe their peers and mentor teachers for the first week of the term, after which they had to teach isiXhosa to classes allocated to them by the school. It is one of the requirements of the PGCE teaching practice that student teachers write reflective journals about their teaching practice. I asked these students to keep special reflective journals for isiXhosa from their first observation visits to schools in the first, second and third terms in 2010 and 2011 respectively. These were the journals I analysed for the purpose of this article.

Following Measor's (1988) and Mouton's (2001) suggestions on accessing research participants, I had to seek student teachers' permission to undertake the study. The students were informed about the purpose of the study and that participation in the study was voluntary. Their right to anonymity and confidentiality was assured and adhered to throughout the study. In this way, I gained their trust and I ensured that interaction with them was carried out with sensitivity and respect.

\section{Research methods}

This study followed a qualitative research design and data was collected by means of an open-ended questionnaire, semi-structured group interviews and document analysis, which involved the analysis of students' reflective journals for triangulation purposes (Strydom \& Delport, 2005; Henning et al., 2004). Triangulation refers to the use of various methods of data collection in order to maintain stability or consistency of research measurements (Mouton, 2001).

First, an open-ended questionnaire was administered to the four PGCE students in 2010, and the same questionnaire was administered to a group of five students in the following year. The questionnaire included several sections that elicited their biographical information (for example, gender, age, home language, highest qualifications, work experience), the number and types of isiXhosa home language lessons they observed and taught during the time they spent in schools, their understanding of teaching practice and their experiences with regard to the teaching of isiXhosa in the classrooms in which they were placed for teaching practice.

Second, it was necessary to complement the questionnaire data with semi-structured interviews in order to increase the accuracy and consistency of the questionnaire data. After a preliminary analysis of the open-ended questionnaires, semi-structured group interviews were conducted with the students: with 4 in 2010 and 5 in 2011. The same procedure was followed in the 2 cohorts for consistency in data collection. Through the interviews, which took approximately 50-55 minutes for both groups, I was able to verify issues that needed further clarity and to probe deeper for additional relevant information, such as their understanding and expectations of teaching practice before they joined the

\section{http://repository.uwc.ac.za}


schools, the nature and quality of support they got from their peers and mentors, their experiences of practising to teach isiXhosa and their reflections on their teaching as student teachers.

Finally, the students' isiXhosa journals were analysed. The analysis of the journals focused on the students' understanding of their new roles and identities in the isiXhosa classrooms, their experiences in the isiXhosa classrooms (that is, what they learnt from their practice, their positive and negative experiences, their suggestions for improvement, the extent to which they could demonstrate their understanding of the relationship between theory and practice in the teaching of isiXhosa) and their ability to reflect on their own teaching practices.

After studying the transcriptions, the data from various sources were coded in order to identify common patterns. The data were then analysed into categories, which were subsequently grouped into broad themes to make meaning of the student teachers' experiences and reflections on the teaching of isiXhosa in the FET phase. The key findings discussed in this article are based on the following themes: student teachers' professional identity and contextual learning, student teacher practices and support, their knowledge and pedagogical strategies, literacy challenges and student teachers' reflections on their own practice.

\section{Research findings \\ Professional identities and contextual learning}

As knowledge is contextualised (Fitzmaurice, 2010), classrooms are authentic spaces in which student teachers learn to create different kinds of knowledge (that is, practical, fundamental and reflexive knowledge). The findings of this study show that the majority of student teachers (7) in both cohorts were exposed to Grade 10 and 11 isiXhosa classes while only 2 of them in the 2011 cohort were exposed to Grade 12 . All the students $(n=9)$ reported more challenges than positive experiences in these classes. Their positive experiences, however, had nothing to do with their teaching practices but reflected the new identities they assumed in terms of exercising authority in managing their own classrooms. Although some of them went to schools with fears and anxiety related to learners' disciplinary problems, their newly constructed identities reinforced their professional status, confidence, sense of responsibility and accountability as new teachers. This finding has elements of mediation as student teachers had to apply their knowledge as mediators of learning in different classroom situations. Given that the majority of students they dealt with came from poverty-stricken backgrounds with high crime rates, they became more sensitive to diverse learners' needs (Grosser \& De Waal, 2008). The contexts in which they worked challenged them to understand the different roles they had to play in their classrooms, ranging from administration, counselling learners with problems, dealing with learners from different backgrounds, etc. The classroom realities strengthened their practical and fundamental competences (Grosser \& De Waal, 2008: 45 ) as they had to exercise power and authority to make informed decisions on their own.

\section{http://repository.uwc.ac.za}




\section{Practice and support}

As stated earlier, student teachers' learning is a mediated and collaborative process which involves peer support, guidance and mentorship through modelling, coaching, feedback and peer support (Darling-Hammond \& Bransford, 2005). However, some student teachers do not get adequate support and opportunities to observe their own educators' or supervisors' modelling of good teaching practices (Rusznyak, 2009: 264).

The findings of this study align with Rusznyak's (2009) observation as most of the student teachers were not provided with observation opportunities. Questionnaire and interview data confirmed that only 1 student $(n=4)$ in the 2010 cohort and 2 students in the 2011 cohort $(n=5)$ were afforded opportunities to observe their isiXhosa subject teachers in the first week of their teaching practice in the third term. This lack of observations was due to subject teachers' administrative commitments such as marking and the finalisation of mid-year reports which were done at the beginning of the third term in some schools. As a result, there was very little or no teaching at all in the first week of the third school term in most of the schools where the student teachers were placed. Student teachers had to assist with marking and marks administration, and some were left alone in classes without guidance.

Most of the students did not get feedback from their mentors, some of whom did not even show interest in the student teachers' teaching. In most cases, the student teachers were left alone in the classrooms and teachers would write fabricated comments in the students' portfolios, without having observed the students' lessons. These comments were provided at the end of the teaching practice period to fulfil the requirements outlined in the student teachers' portfolios. This kind of feedback does not have any value for the student teachers' growth in terms of practice and independent learning (Rusznyak, 2009). This means that the student teachers had to navigate learning to teach on their own, with no guidance from experienced teachers. This finding corresponds with what Whitelaw, De Beer and Henning (2008) observed with beginner teachers who learn on the job on a trial and error basis due to lack of support structures in many schools. Due to such lack of support in schools, both beginner and prospective teachers begin to develop negative attitudes towards the teaching profession (Darling-Hammond \& Bransford, 2005).

Despite the above student teachers' negative experiences, it is worth mentioning that there are good teachers, whose work is often not acknowledged as many researchers only report on what teachers cannot do rather than what they can do (Swart \& Oswald, 2008; Fritz \& Smit, 2008). It is not the aim of this article to express pessimism and hopelessness with regard to isiXhosa teaching but to explore both positive and negative experiences as a means of identifying possible strategies to improve the status quo. In this study, three students (one in the 2010 cohort and two in the 2011 cohort) reported good support, feedback and good relationships with their mentors, which reinforced their confidence and enthusiasm as prospective isiXhosa teachers. In their observations, they experienced

\section{http://repository.uwc.ac.za}


creative and innovative teaching strategies in which learners were actively involved in activities such as isiXhosa debates with other schools, writing of short stories, poems and drama, etc. which were published as a collection. Their mentor teachers were dedicated and determined to teach properly in order to produce work of good quality in the isiXhosa classroom. This means that the negative reports on some isiXhosa teachers cannot be generalised, and it is imperative that dedicated teachers be recognised and commended for their good work.

\section{Subject content knowledge and pedagogical practices}

The study data shows that compiling study notes was the most dominant strategy used in isiXhosa classes. For example, seven students (three of the 2010 cohort and four of the 2011 cohort) mentioned that most of their teaching was dependent on writing notes for learners as there were not sufficient textbooks to use when teaching. Whilst the value of compiling study notes as one of the teaching strategies cannot be dismissed, it is time consuming and does not allow interaction between the teacher and learners.

In this study, student teachers showed an understanding of learner-centred teaching approaches, but lack of resources in schools did not facilitate this strategy. In fact, some of the student teachers confessed that they were taught in the same way by their teachers while they were still at school, that is, they were required to take down notes due to lack of resources such as isiXhosa textbooks in their former schools. This kind of practice ties in with Korthagen and Kessels' (1999) notion of the 'transfer problem' which usually influences prospective teacher practices. Transfer problems are usually rooted in the teachers' own schooling backgrounds, how they were taught and their learning styles. It explains how teachers' prior knowledge and preconceptions about teaching influence their practice. The preconceptions could be dominated by rote learning which may become resistant to change and become part of their practice regardless of exposure to new knowledge (Rusznyak, 2009; Korthagen \& Kessels, 1999).

While teaching involves preparation and having adequate knowledge about the lesson content (Jordaane \& Pillay, 2009), students' responses show that there was little preparation for isiXhosa lessons in some of the schools. For example, four students (two in the 2010 cohort and two in the 2011 cohort) reported that they did not have sufficient time to prepare for their isiXhosa lessons as they were given lessons to teach either at the end of each day or early in the mornings. This occurred despite the fact that student teachers visited the schools before the end of the second term to meet with mentors or subject teachers and to collect lessons to teach in the third term. This exercise impacted negatively on student teachers' confidence and practice, and it had implications for the quality of their subject content knowledge and pedagogical knowledge. This finding shows that there are tensions between the theoretical knowledge that student teachers bring to schools and what they are forced to do (practice) in real classroom situations, which sometimes negatively affects their teaching practices (Korthagen \& Kessels, 1999; Appleton \& Harrison, 2001).

\section{http://repository.uwc.ac.za}




\section{FET learners' literacy problems}

The questionnaire and interview data revealed that many isiXhosa lessons observed (by those who were afforded the opportunity to observe) and taught by student teachers focused more on oral skills and grammar than on reading and writing. This finding corresponds with Murray's (2009:29) observation that African language teaching focuses strongly on grammar learning. Learners' low literacy levels observed by student teachers may not be directly linked to this observation, but could be attributed to a lack of isiXhosa reading materials. However, this finding raises a concern, given that FET learners are at the exit level of schooling towards tertiary education where strong academic literacy skills are required.

This finding confirms the literacy crisis in South African schools as reported in the Progress in International Reading Literacy Study (PIRLS) (Howie et al., 2006) and in the latest Annual National Assessment (DBE, 2011) in the General Education and Training (GET) band. It alerts student teachers to areas that need more attention in language teaching, such as learners' reading and writing skills, as suggested by Dornbrack (2009).

\section{Reflections on teaching practices}

Reflective practice is at the centre of effective teaching (Jordaane \& Pillay, 2009; Rusznyak, 2009; Ashby et al., 2008; Grosser \& De Waal, 2008; Kemmis, 2011). As it is a cyclical process that involves monitoring, evaluating and revising one's own practices (Pollard, 2005: 14), it is associated with mediated learning and better quality of teaching and learning. It enables student teachers to identify areas of improvement in their practice and to devise alternative pedagogical strategies for effective teaching (DarlingHammond \& Bransford, 2005). This implies that placing student teachers in schools for teaching practice does not necessarily facilitate effectiveness in their teaching practice if they are not exposed to situations that challenge their preconceived ideas about teaching practice, or are not required to explain and justify their decisions and actions in teaching.

In this study, student teachers' reflections were mainly a description of their emotions and experiences during teaching practice. They did not clearly illustrate how they monitored their teaching practices. The evaluation of their own practice was based on the success of their lessons only, for example, their level of preparedness, their ability to manage the class, the amount of work given to learners, and the learners' understanding of the lesson or their ability to answer questions on the lesson. They could not go beyond this description to justify their own actions or practices in the lessons they taught and how to improve or revise their practices in relation to what they were taught in the theory classes and what they were exposed to in the isiXhosa classrooms. This was an indication that student teachers were struggling to contextualise their acquired knowledge and to make a connection between the different types of knowledge to enhance their teaching practices. This indicates that they could not apply their knowledge to understand, explain and justify their own teaching practices in the isiXhosa lessons.

\section{http://repository.uwc.ac.za}


Teacher education and the teaching of African languages in the 21st century

While acknowledging the influence of practising teachers' and student teachers' identities, prior experiences, beliefs and backgrounds in language teaching (Jordaane \& Pillay, 2009; Murray, 2009), it is crucial that all language teachers, including prospective teachers, adopt innovative pedagogies for the 21st century classroom. This entails strengthening teacher education programmes (both pre-service and in-service) by training competent African language teachers (DHET, 2008) who are not only proficient in the languages, but who are capable of mediating learning by responding to the diverse needs of their learners, and who constantly reflect upon and learn from their own experiences in the classroom (Grosser \& De Waal, 2008).

As the outcomes-based curriculum envisages learners who are literate, numerate, multiskilled and independent (DoE, 2005), teacher education programmes should be able to respond positively to the envisaged learner competences. The starting point would be to develop student teachers' literacy in African languages as it is often taken for granted that when students enter ITEP they have well-developed literacy skills in these languages. Therefore, ITEP should prioritise modules and activities that will develop student teachers' literacy skills, particularly in their African languages so that they will be able to transfer those skills to their learners.

Given the lack of teaching and learning resources in African languages, teacher education programmes and schools should focus on materials development in these languages. These materials can be piloted in schools so that they can be utilised in meaningful ways with experienced teachers. School learners can produce their own materials, for example, posters, pamphlets, booklets, etc. under the guidance of their teachers and parents. Nowadays learners bring digital literacy to the classroom - the ability to use digital resources such as cellphones, computers, and the Internet (Eshet-Alkali \& AmichaiHamburger, 2004). This opens a wider scope for exploring various tasks, which include developing multimodal texts such as stories, poems, posters, photos, etc. as part of the visual and media literacy requirements promoted by the outcomes-based curriculum (DoE, 2005). Use of digital resources in African languages can be useful in terms of mediating learning and designing teaching and learning resources. Therefore, Information and Communications Technology (ICT) should be part of ITEP and Continuing Professional Development (CPD) design, particularly in African languages, as teachers have much to learn in using new technology for teaching and learning.

Schools have a responsibility in teacher development (Whitelaw et al., 2008). This implies that preparing teachers for the classroom involves schools and institutions of higher education or universities. Therefore, schools and universities should work collaboratively to produce teachers of good quality who will be able to make a difference, particularly in the teaching of African languages. This entails regular teacher development programmes in African languages, which could be part of Continuing Professional

\section{http://repository.uwc.ac.za}


Development (CPD) for practising teachers.

Prospective and practising teachers should be empowered with creative and innovative strategies for language teaching in order to nurture and develop the language skills brought into the classroom by students, for example, digital or technological skills. Teachers and teacher educators should provide authentic and supportive spaces for practice through well-planned demonstration lessons, micro-teaching, use of video clips, etc. In this way student teachers learn to relate their coursework to the classroom and learners, that is, 'learning in and from practice' (Ball \& Cohen, 1999, cited by DarlingHammond, 2005: 402).

As stated earlier, research into African language teaching is very limited. ITEP should encourage a culture of students' research, particularly in African languages which are lagging behind in terms of innovative pedagogy. Research by practising and prospective teachers, particularly action research, will enable them to make sense of teaching practice and challenge them to think about what they are doing and how to improve their own teaching practices. Likewise, African language teacher educators should be engaged in an ongoing reflective research-based practice to ensure that their language modules address local needs while they match international standards in terms of cognitive or academic and professional depth.

\section{Conclusion}

In this article I have shown that student teachers had somewhat negative experiences of isiXhosa teaching in schools. Their negative experiences illuminated various challenges regarding mentor- ship support, teaching resources, pedagogical issues, learners' literacy skills and student teachers' reflective practices. Student teachers' negative experiences in the classroom contribute to shaping their view of teaching and their own practice.

The article has also indicated that preparing student teachers to teach isiXhosa is a challenging task that cannot be ignored, as it has implications for ITEP design and the quality of teachers produced to teach this language. At the moment there are few African language teacher educators who can provide good quality tuition to student teachers. Given that isiXhosa is offered as a home language from primary to tertiary education, it is crucial that teacher education programmes produce quality teachers who are well prepared to make innovative changes in developing this language as an academic or intellectual language of high function. There is a need to improve the competence and pedagogical skills of African language teachers who are already in the system through inservice training programmes so that they can improve their teaching practices in their own classrooms and become good role models to prospective teachers.

Although the findings of the study cannot be generalised due to the small sample used in data collection, they clearly reflect the lack of planning and the low teacher morale and motivation that are prevalent in many South African schools. These challenges should be

\section{http://repository.uwc.ac.za}


taken seriously if South Africa wants to address educational challenges, including the development of African languages. Education faculties should attract more African language speaking students and prioritise the teaching of African languages as home languages, as they are used as languages of teaching and learning in the Foundation Phase. They should also strengthen academic leadership in African languages through research grants and collaborative research projects, which should aim at improving research whilst strengthening the quality of teaching in African languages. Therefore, teacher preparation should involve teamwork efforts by researchers, teacher educators and experienced teachers who are committed to nurture and support young African language teachers so that they can make a significant contribution towards the quality of teaching these languages, not only in terms of learners' intellectual or cognitive development, but also in ways that respond to the challenges and needs of the 21st century classroom. 


\section{References}

Alidou H. 2004. Medium of instruction in post colonial Africa. In: Tollefson JW \& Tsui $\mathrm{ABM}$ (eds), Medium of instruction policies: Which agenda? Whose agenda? New Jersey: Lawrence Erlbaum Associates, pp 195-214.

Appleton K \& Harrison A. 2001. Outcomes-based science units that enhance primary and secondary science teachers' PCK. Paper presented at the Australian Association for Research in Education (AARE) Conference, Freemantle 2011.

Ashby P, Hobson AJ, Tracey L, Malderez A, Tomlinson PD, Roper T, Chambers GN \& Healy J. 2008. Beginner teachers' experiences of initial teacher preparation, induction and early professional development: A review of literature. University of Nottingham: Department for Children, Schools and Families.

Brock-Utne B. 2005. The continued battle over Kiswahili as the language of instruction in Tanzania. In: Brock-Utne B \& Kofi Hopson R (eds), Languages of instruction for emancipation: Focus on postcolonial contexts and considerations. Dar es Salaam: Mkuki na Nyota Publishers. pp 231-255.

Darling-Hammond L \& Bransford J (eds). 2005. Preparing teachers for a changing world. San Francisco: Jossey-Bass. pp 90-441.

DBE (Department of Basic Education). 2011. Report of the Colloquium on Language in the Schooling System. Pretoria.

DBE (Department of Basic Education). 2011. Report on the Annual National Assessment of 2011. Pretoria.

DHET (Department of Higher Education and Training). 2008. National Qualifications Framework, Act 67. Draft Policy on the Minimum Requirements for Teacher Education Qualifications Selected from the Higher Education Qualifications Framewok (HEQF). Pretoria: Government Printers.

DoE (Department of Education). 1997. Language in Education Policy. Pretoria.

DoE (Department of Education). 2005. National Curriculum Statement. Pretoria.

Dornbrack J. 2009. Our multilingual context: Teaching language in the South African context. In: Ferreira A (ed.), Teaching language. Northlands: Macmillan South Africa, pp 25-40.

Desai Z. 2003. A case for mother tongue education? In: Brock-Utne B, Desai Z \& Qorro M (eds), Language of instruction in Tanzania and South Africa (LOITASA). Dar-esSalaam: E \& D Limited, pp 45-68.

De Vos AS, Strydom SH, Fouche CB \& Delport CSL. 2005. Research at grassroots (3rd edn). Pretoria: Van Schaik Publishers.

Eshet-Alkali Y \& Amichai-Harmburger Y. 2004. Experiments in digital literacy. CyberPsychology and Behaviour 7 (4): 421-428.

Fitzmaurice M. 2010. Considering teaching in higher education as a practice. Teaching in Higher Education 15(1): 45-55.

Foley A. 2001. Mother tongue education in South Africa. Available at http://englishacademy.co.za/ pansalb/education.pdf [accessed 13 April 2012].

Fritz E \& Smit B. 2008. Ethnographic narratives challenging problem saturated stories of teacher inefficiency. Education as Change 12(2): 155-169.

\section{http://repository.uwc.ac.za}


Grosser M \& De Waal E. 2008. Recentering the teacher: From transmitter of knowledge to mediator of learning. Education as Change 12(2): 41-57.

Gxilishe S. 2009. Afrikaans, African languages and Indigenous Knowledge Systems - the connection. Paper presented at the Roots Conference, University of the Western Cape, Cape Town, 2009.

Henning E, Van Rensburg W \& Smit B. 2004. Finding your way in qualitative research. Pretoria: Van Schaik Publishers.

Heugh K. 2003. Language policy and democracy in South Africa. PhD thesis, University of Stockholm.

Howie S, Venter E \& Van Staden S. 2006. The effect of multilingual policies on performance and progression in reading literacy in South African primary schools. Available at http://hdl.handle. net/2263/9776 [accessed 3 November 2011].

Jordaane S \& Pillay R. 2009. Beginning my journey of professional development: The language teacher and the teaching profession. In: Ferreira A (ed.), Teaching language. Northlands: Macmillan South Africa. pp 1-10.

Kemmis S. 2011. What is professional practice? Recognizing and respecting diversity in understandings of practice. In: Kanes C (ed.), Elaborating professionalism: Studies in practice and theory. New York: Springer. pp 139-165.

Korthagen FAJ \& Kessels JPAM. 1999. Linking theory and practice: Changing the pedagogy of teachers' education. Educational Researcher 28(4): 4-7.

Mbatha T. 2010. Putting the end point at the beginning: Teachers' understanding of using a dual medium approach for teaching literacy in Foundation Phase classrooms. Alternations 17(1): 49-71.

McKay S \& De Klerk V. 1996. The effect of second language education on academic achievement in a Std 10 history class. Language Matters 27(1): 197-221.

Measor L. 1988. Interviewing: A strategy in qualitative research. In: Burgess RG (ed.), Strategies of educational research: Qualitative methods. London: The Falmer Press. pp 55-77.

Mouton J. 2001. How to succeed in your master's and doctoral studies: A South African guide and resource book. Pretoria: Van Schaik Publishers.

Murray S. 2009. Making sense of the new curriculum: Understanding how the new curriculum works and what it means for language teachers. In: Ferreira A (ed.), Teaching language. Northlands: Macmillan South Africa. pp 11-24.

Mwinsheikhe HM. 2003. Using Kiswahili as a medium of science teaching in Tanzanian secondary schools. In: Brock-Utne B, Desai Z \& Qorro M (eds), Language of instruction in Tanzania and South Africa (LOITASA). Dar es Salaam: E \& D Limited. pp 129-139.

Nomlomo V. 2007. Science teaching and learning through the medium of English and isiXhosa: A comparative study at two primary schools in the Western Cape. PhD thesis, University of the Western Cape.

Ohta AS. 2000. Rethinking interaction in SLA: Developmentally appropriate assistance in the Zone of Proximal Development and the acquisition of L2 grammar. In: James P (ed.), Sociocultural theory and second language learning. New York: Oxford

\section{http://repository.uwc.ac.za}


University Press. pp 51-78.

Pluddeman P, Nomlomo V \& Jabe N. 2010. Using African languages for teacher education. Alternations 17(1): 72-91.

Pollard A. 2005. Reflective teaching (2nd edn). London: Continuum.

Qorro M. 2003. Unlocking language forts: Language of instruction in post-primary education in Africa - with special reference to Tanzania. In: Brock-Utne B, Desai Z \& Qorro M (eds), Language of instruction in Tanzania and South Africa (LOITASA). Dar es Salaam: E \& D Limited. pp 187-196.

Republic of South Africa Census. 2001. Available at http://www.statssa.gov.za [accessed 12 February 2012].

Roy-Campbell ZM. 2006. The state of African languages and the global language politics: Empowering African languages in the era of globalization. Selected Proceedings of the 36th Conference on African Linguistics. MA Cascadilla Proceedings Project. pp $1-13$.

RSA (Republic of South Africa). 1996. Constitution of the Republic of South Africa. Pretoria: South Africa. Government Printers.

Rusznyak L. 2009. Confronting the 'Pedagogical Immunity' of student teachers. Education as Change 13(2): 263-276.

Sentson C. 1994. The effect of language of presentation on the pupils' performance in a mathematics test. South African Journal of Education 14(3): 109-115.

Shrum JL \& Glisan EW (eds). 2000. Teacher's handbook - contextualized language instruction (2nd edn). USA: Heinle \& Heinle.

Strydom H \& Delport CSL. 2005. Document study and secondary analysis. In: De Vos AS, Strydom H, Fouche CB \& Delport CSL (eds), Research at grassroots (3rd edn). Pretoria: Van Schaik Publishers. pp 314-325.

Swart E \& Oswald M. 2008. How do teachers navigate their learning in developing inclusive learning communities? Education as Change 12(2): 91-108.

UNESCO. 2010. Why and how Africa should invest in African languages and multilingual education: An evidence and practice-based policy advocacy brief. Germany: Institute for Lifelong Learning.

Vuzo M. 2005. Using English as a medium of instruction in Tanzanian schools: Problems and prospects. In: Brock-Utne B, Desai Z \& Qorro M (eds), LOITASA Research in Progress. Dar-es- Salaam: KAD Associates. pp 55-82.

Vygotsky LS. 1978. Mind in society: The development of higher psychological processes. Cambridge: Harvard University Press.

Webb V. 2004. Language policy in post-apartheid South Africa. In: Tollefson JW \& Tsui ABM (eds), Medium of instruction policies: Which agenda? Whose agenda? New Jersey: Lawrence Erlbaum Associates. pp 217-240.

Whitelaw S, De Beer J \& Henning E. 2008. New teachers in a pseudocommunity of practitioners. Education as Change 12(2): 25-40. 